\title{
In Pursuit of Prehistoric Caribou on Thandlät, Southern Yukon
}

\author{
GERALD W. KUZYK, ${ }^{1}$ DONALD E. RUSSELL,${ }^{2}$ RICHARD S. FARNELL,${ }^{1}$ RUTH M. GOTTHARDT $, 3,5$ \\ P. GREGORY HARE, ${ }^{3}$ and ERIK BLAKE ${ }^{4}$
}

(Received 15 June 1998; accepted in revised form 27 November 1998)

\begin{abstract}
In 1997, the first author noted a large concentration of caribou (Rangifer sp.) fecal pellets and a caribou antler on a permanent snow patch in the Kusawa Lake area of southern Yukon. Caribou are completely absent from this area today. Coring of the snow patch revealed continuous deposits of fecal pellets to depths of at least $160 \mathrm{~cm}$. The proximal portion of a wooden dart or arrow shaft fragment recovered on the edge of the snow patch represents one of the few organic examples of mid-Holocene hunting technology ever found in Canada. An age of $2450 \mathrm{BP} \pm 50$ years was obtained for the fecal material from approximately $1.6 \mathrm{~m}$ below the surface of the snow patch, and the dart was dated at $4360 \mathrm{BP} \pm 50$ years. These dates indicate that aboriginal Yukon hunters have been harvesting caribou at this location for at least 4000 years. The Thandlät site offers a rare opportunity to explore a number of questions regarding the prehistoric ecology of large caribou populations, the implications of climate change for caribou populations, and human use of high-elevation hunting sites.
\end{abstract}

Key words: woodland caribou, Rangifer tarandus caribou, permanent snowfield, environmental change, prehistoric dart, southern Yukon

RÉsumÉ. En 1997, le premier auteur a découvert une concentration élevée de boulettes fécales (Rangifer sp.) et des bois de caribou sur une congère dans la région du lac Kusawa, dans le sud du Yukon. Il n'y a plus de caribous dans cette région. Le carottage de la congère a révélé des dépôts de boulettes jusqu'à une profondeur de $160 \mathrm{~cm}$. Un fragment de dard ou de la flèche en bois trouvé sur le bord de la congère représente une des rares découvertes au Canada relatives à ce type d'arme. Il a été déterminé que les matières fécales prélevées dans la congère, à environ $1,6 \mathrm{~m}$ de profondeur, sont âgées de $2450 \mathrm{BP} \pm 50$ ans, et que le dard aurait $4360 \mathrm{BP} \pm 50$ ans. Ces dates montrent que les Autochtones du Yukon chassaient déjà le caribou à cet endroit il y a 4000 ans. Le site Thandlät est un des rares endroits où l'on peut observer divers aspects préhistoriques des grandes populations de caribou, des effets des changements climatiques sur les populations de caribous et des activités de chasse à grande altitude.

Mots clés: caribou des bois (Rangifer tarandus caribou), champ de neige permanente, changements environnementaux, dard préhistorique, sud du Yukon

\section{INTRODUCTION}

This paper presents the preliminary data resulting from the accidental discovery in 1997 of large concentrations of caribou dung and evidence of prehistoric human hunting on a permanent alpine snow patch in southern Yukon. Its purpose is to draw attention to the potential of such sites for the preservation and recovery of environmental, biological, and cultural information possibly spanning several thousand years.

On 31 August 1997, the first author discovered a large concentration of caribou (Rangifer sp.) fecal pellets and a caribou antler on a permanent snow patch on Thandlät Ddhäl ("sharp, pointed mountain" in the Southern Tutchone language) in the Kusawa Lake area of southern Yukon (Figs. 1 and 2). The snow patch is at $1830 \mathrm{~m}$ above sea level in a north-facing alpine basin. The observation commanded immediate interest, as caribou do not presently occupy this area; the last reported herds were seen in the winter of 1932 (Jimmy G. Smith, Ta'an Kwach'an First Nation, pers. comm. to Sarah Gaunt, Champagne and Aishihik First Nations Heritage Office, 1998).

The distribution and depth of caribou fecal pellets (up to $30 \mathrm{~cm}$ thick at the base of the slope) on the surface of the site appear to result from recent and rapid melting of the alpine snow patch. Fecal pellets observed atop large boulders at the edge of the ice indicate that as much as $60 \mathrm{~cm}$ ice ablation may have occurred in recent years. These surface pellets likely were deposited in the 19th century, when caribou were last resident in the area.

\section{METHODS}

In the month following the initial discovery, two brief site inspections were made at the Thandlät snow patch. On

\footnotetext{
${ }^{1}$ Department of Renewable Resources, Box 2703, Whitehorse, Yukon Y1A 2C6, Canada

${ }^{2}$ Canadian Wildlife Service, Environment Canada, 91782 Alaska Highway, Whitehorse, Yukon Y1A 5B7, Canada

${ }^{3}$ Heritage Branch, Government of Yukon, Box 2703, Whitehorse, Yukon Y1A 2C6, Canada

${ }^{4}$ Icefield Instruments Inc., Box 5567, Whitehorse, Yukon, Y1A 5H4, Canada

${ }^{5}$ Corresponding author: Ruth.Gotthardt@gov.yk.ca

(C) The Arctic Institute of North America
} 


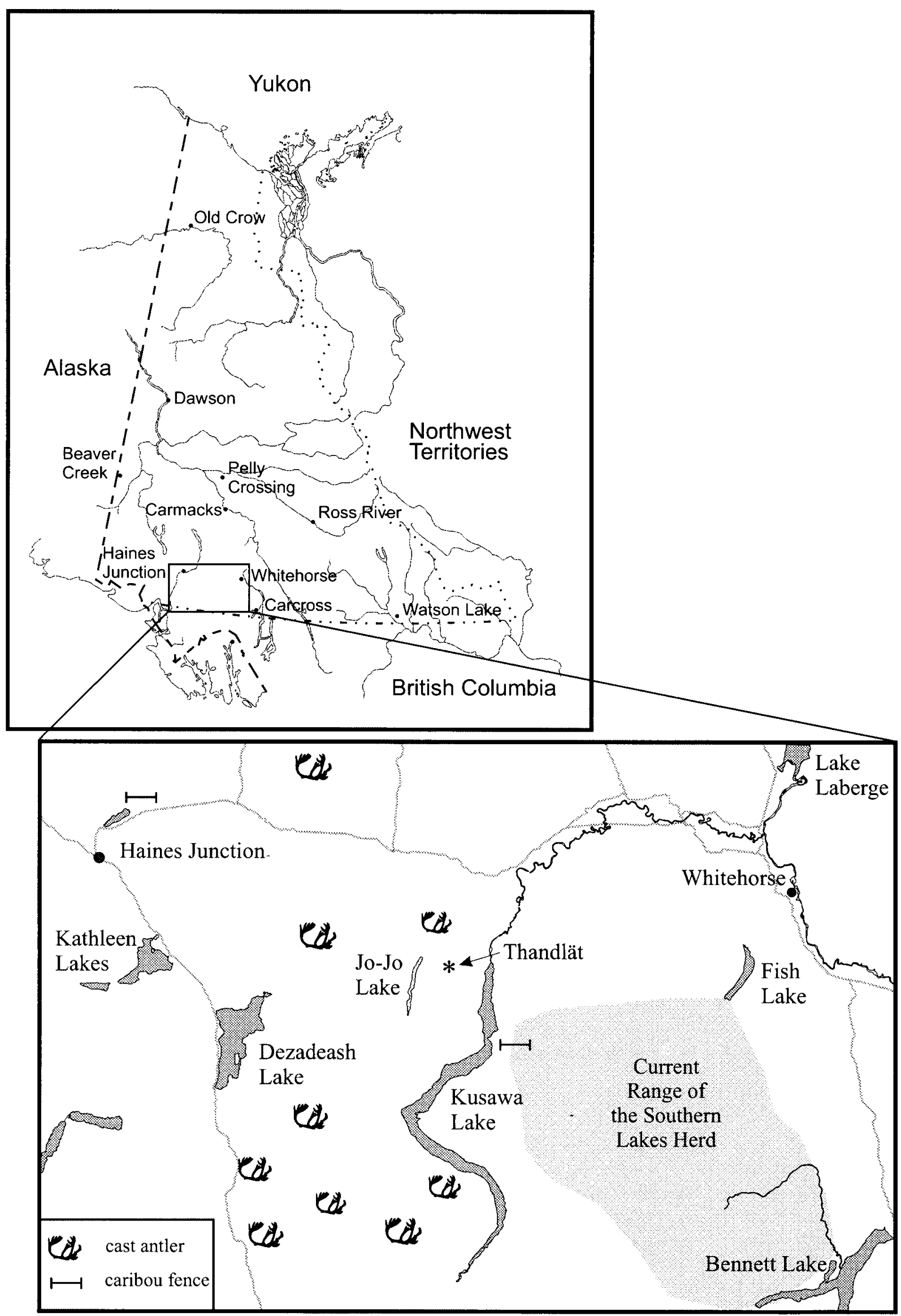

FIG. 1. Map of the site location in the southwest Yukon. 


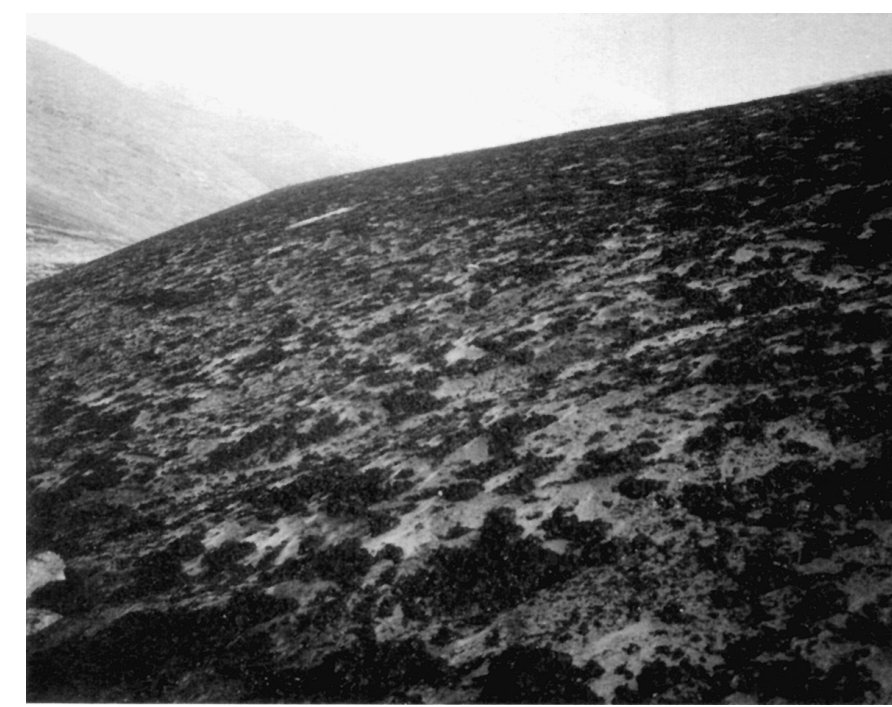

FIG. 2. View of a portion of the Thandlät snow patch, showing extensive deposits of caribou dung exposed by melting. The snow patch is about $750 \mathrm{~m}$ long by $300 \mathrm{~m}$ wide, with a slope of approximately $40^{\circ}$.

12 September 1997, small quantities of fecal pellets were collected from several localities on the surface of the snow patch for dietary analysis. In addition, several faunal samples were collected, including a caribou mandible, a long bone fragment, and a small clump of hair. The proximal end of a feathered dart or arrow shaft was recovered on the edge of the snow patch. The site was revisited on 29 September 1997. A $205 \mathrm{~cm}$ Sipre ice core auger was used to sample subsurface ice deposits. A core of ice approximately $160 \mathrm{~cm}$ long revealed caribou fecal pellets present intermittently throughout the core to the base. Planned survey of the site for additional biological and cultural materials was prevented by a fall of snow that had occurred the previous night.

A frozen fecal pellet from the base of the ice core (160 $\mathrm{cm}$ below surface) was submitted to Isotrace Laboratories at the University of Toronto for AMS radiocarbon dating. A small portion of the wooden dart fragment was also submitted for AMS dating. The faunal samples collected from the Thandlät site were sent to the Department of Biological Sciences, University of Alberta, for DNA fingerprinting to confirm species identification. Surface fecal pellets were submitted to the Habitat Nutrition Laboratory, Washington State University, for plant fragment analysis.

\section{RESULTS}

Samples submitted to Isotrace laboratories for AMS dating yielded the following results: the caribou fecal pellet from the base of the ice core returned a date of 2450 B.P. \pm 50 (TO-6871); the dart shaft fragment was dated at 4360 B.P. \pm 50 (TO-6870). With ice thickness estimated at $5-10 \mathrm{~m}$, it is possible that the Thandlät snow patch contains a record of ice with layers of caribou fecal pellets extending back in time more than 4000 years.

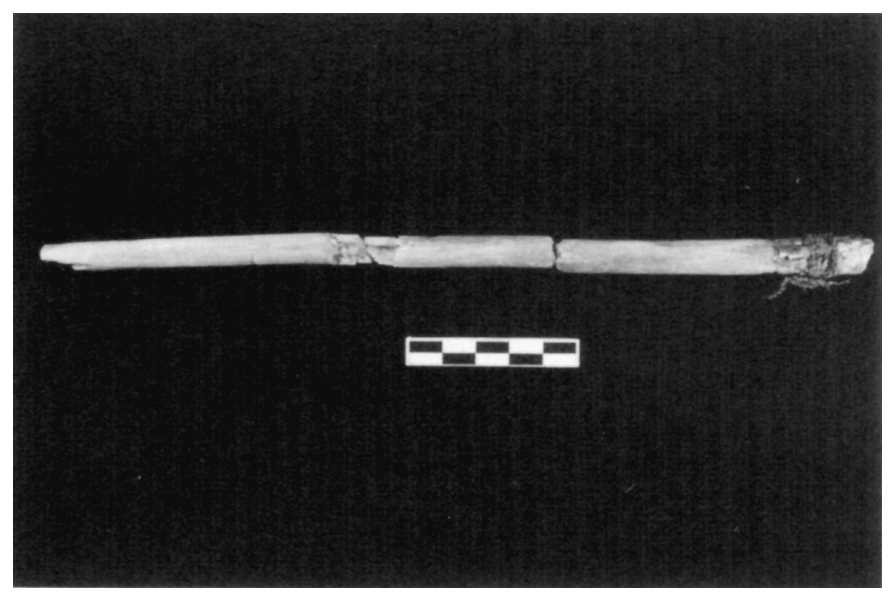

FIG. 3. Thandlät dart/arrow fragment.

The results of the DNA analysis to identify caribou species (woodland vs. barren-ground) have not as yet been received. Results of the plant fragment analysis carried out by the Habitat Nutrition Laboratory at Washington State University indicate that the diet of the Thandlät caribou consisted mainly of sedge (36\%), lichen (23\%), moss $(11 \%)$, and grass $(10 \%)$. No summer food habit studies have been conducted on caribou in southern Yukon. However, work done on the Porcupine Caribou Herd (PCH) in northern Yukon indicates that during the insect harassment period (June-August), animals feed mainly on emerging willow leaves $(47 \%)$ and herbs $(36 \%)$, with a minor component of lichens (10\%) (Russell et al., 1993). At this time of year, animals are seeking the highest available nitrogen source from the environment. Diet results from the present study are more similar to the spring diet of the $\mathrm{PCH}$, which has greater quantities of sedges and moss, than to the herd's lichen-dominated winter diet. The high amount of grass in the diet was not noted in the PCH. This comparison indicates that members of the present Porcupine Caribou Herd obtain more nitrogen (required for lactation) than did their ancient Thandlät cousins. However, contemporary summer diet studies in the southern Yukon would provide a more direct comparison to the results of the present study.

The wooden dart or arrow shaft fragment recovered on Thandlät provides the material evidence that prehistoric hunters exploited the former seasonal caribou aggregations at this locality (Figs. 3 and 4) and is a rare example of organic hunting technology of the mid-Holocene period.

The artefact was discovered in three pieces on the edge of the snow patch. The reassembled dart fragment measures $24.5 \mathrm{~cm}$ long; at the proximal end, it is $1.08 \mathrm{~cm}$ thick; at the distal end, $0.88 \mathrm{~cm}$ thick. The thickness of the fragment suggests the original length of the complete dart was unlikely to have been very great-perhaps no more than about $50 \mathrm{~cm}$.

The dart was fletched with two feathers tied to the shaft by a short piece of twisted sinew. All that remains of the feathers are the sections of the quill immediately under the 


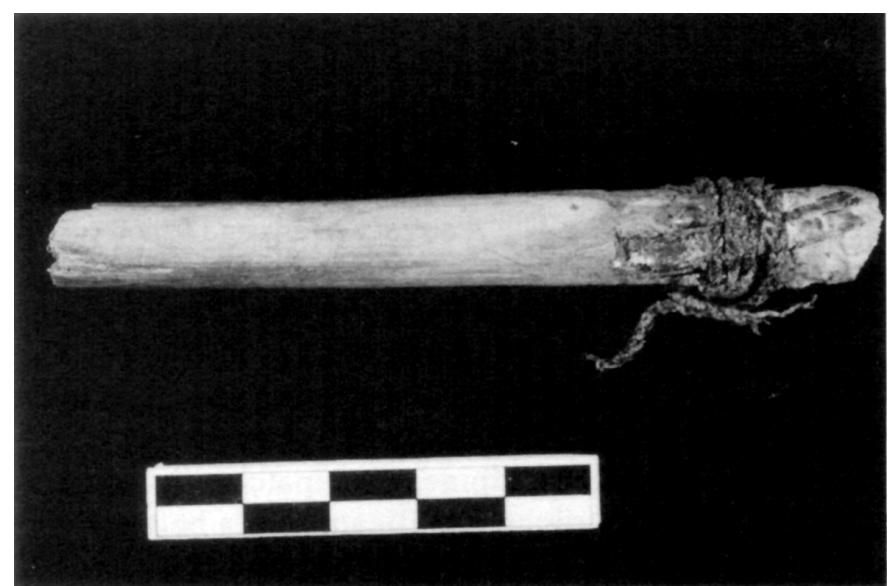

FIG. 4. Close-up of the fletched end of the dart/arrow, showing a remnant of the feather shaft under the sinew tie. Scale is in centimetres.

sinew tie. The feathers are as yet unidentified as to species. The feathers are split, but the halves remain attached by the keratinous outer membrane and lie open against the shaft. It is not possible to determine if the feathers were tied near the top as well as at the bottom, as the extreme proximal end of the dart shaft is missing.

The sinew tie is remarkable in its workmanship: the tie is composed of two or three fine strands of sinew tightly twisted together to form a uniform cord (cf. McClellan, 1975:266 for a description of preparing and twisting sinew thread). On this piece, the sinew tie exhibits a "Z" twist, and the strands are rolled counterclockwise. The finished product is about $0.15 \mathrm{~cm}$ in width. The tie is wrapped four times around the shaft to hold the feathers and appears originally to have been knotted.

The shaft of the dart is overall quite uniformly round with only occasional whittling or shaving planes and nicks. Three narrow, shallow grooves were noted around the circumference of the shaft: one is $2.97 \mathrm{~cm}$ below the proximal end of the shaft (immediately below the feathers); one is $10.87 \mathrm{~cm}$ below the proximal end, at about midpoint; and the third is approximately $18.14 \mathrm{~cm}$ below the proximal end. Experimentation with a replica birch arrow suggests that these marks may be due to compression from something tied around the shaft, rather than being incised grooves. The wood used in the manufacture of the dart shaft has not yet been identified, but well-documented preferences in the ethnographic record suggest it is likely to be birch (Betula papyrifera).

\section{DISCUSSION}

\section{The Biological Evidence}

The high percentage of lichen found in the pellet sample indicates that caribou rather than Dall sheep (Ovis dalli) were responsible for the fecal pellet concentration on Thandlät (Hoefs and McTaggart-Cowan, 1979).

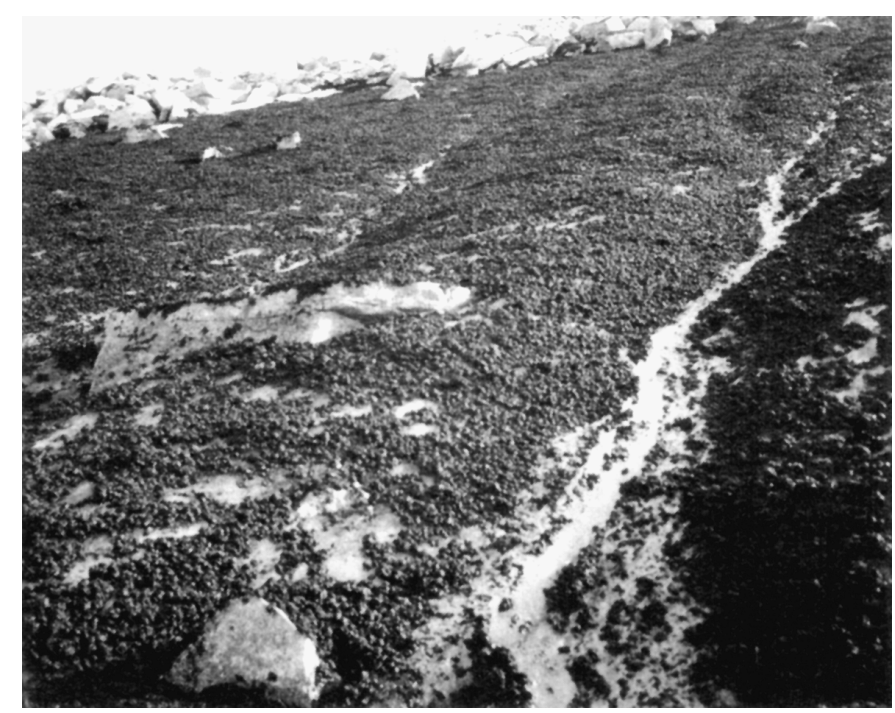

FIG. 5. View of line of boulders above Thandlät snow patch that may have been used as a hunting blind.

Pending the results of the DNA analysis, the question remains as to which caribou species is represented at Thandlät: woodland or barren-ground. Studies have been conducted on a woodland caribou (Rangifer tarandus caribou) herd occupying a range less than $50 \mathrm{~km}$ from the study site (O'Donoghue, 1996). These animals spend the summer and fall in the mountains, where they calve and rut, and then, with increasing snow depths in winter, make short migrations to lowland valleys (Farnell et al., 1996). It is believed that this herd was once much larger but declined during the Klondike Gold Rush in the late 1800s, when a large number of people passed through and moved into the region. The herd is now reduced to three small fragmented herds with about 450 caribou each (O'Donoghue, 1996). Such herd fragmentation may have been the fate of the caribou using the study site. Although caribou are absent from the area today, oral history accounts indicate that they were common and even sufficiently numerous in the past to warrant construction of a caribou fence in the uplands west of Kusawa Lake (Cruikshank, 1985).

Other possible caribou that could have occupied the site may have been the Fortymile herd, a barren-ground caribou (Rangifer tarandus granti) herd that historically occupied a large area from Fairbanks, Alaska to Whitehorse, Yukon. This herd, which numbered over 500000 in the late 1800 s, now numbers less than 25000 and is largely confined to Alaska (Boertje and Gardner, 1996). Pregnant cows gather in large groups on core calving grounds in Alaska, then migrate eastward in fall, occasionally wintering in the Yukon. Local knowledge of the Fortymile herd suggests that when the herd was large, caribou would be in the central Yukon during summer and reach the boreal forests of southern Yukon during winter only. It seems unlikely that wintering caribou could have been the source of fecal material on a perennial snow patch. We therefore 
assume caribou of the Southern Lakes herd (woodland caribou) deposited the concentration of fecal pellets.

We speculate that the fecal pellets were deposited during summer (late June to mid-August) when caribou congregate on snow patches during hot weather for thermal regulation and relief from insect harassment (Ion and Kershaw, 1989).

\section{The Evidence for Prehistoric Hunting}

On the basis of its size and the presence of feathers at one end, the Thandlät dart fragment was initially identified as an arrow. In the ethnographic record of southwest Yukon, three feathers (split or intact) were usually tied onto an arrow shaft at both the top and the base of the feather (McClellan, 1975). However, the date of greater than 4000 years obtained for the dart raises the possibility that the specimen may be a dart propelled by a dart thrower or throwing stick, or whip sling. The assumption here is that bow-and-arrow technology appeared in North America relatively recently (after 4000 years ago) as a result of contact with Palaeoeskimo populations (Blitz, 1988; McGhee, 1989). However, Ackerman's (1996) recent identification as arrows of a slotted bone/antler point in the 9500-year-old deposits at Lime Hills, Cave 1, and the similarly dated bone point from Trail Creek Cave requires the question of the antiquity of bow-and-arrow technology be left open.

Although dart throwers (Hutchings and Brüchert, 1997) are not reported in the ethnographic record for the Southern Yukon, whip slings, which make use of arrows or arrow-sized darts, are documented in traditional Southern Tutchone technology and in the adjacent Tlingit culture area (de Laguna, 1972; McClellan, 1975; Emmons, 1991). Differences in how the dart is propelled distinguish throwing sticks and whip slings: the latter utilize the additional whip action of a string attached to a throwing stick to propel the dart.

The presence of a dart or arrow shaft fragment at the Thandlät snow patch suggests continuity in a particular alpine hunting pattern over some 4000 years. Heat and insect harassment combine to render caribou easy prey on ice patches in the summer. And summer hide of the animals, with its shorter hair, was preferred traditionally for clothing manufacture (Cruikshank, 1985). The oral history record may shed some light on specifics of this hunting strategy, which perhaps involved the use of hunting blinds at the location of present or former snow patches. Hunting blinds constructed of boulders are documented in the prehistoric record in the mountains between Kusawa and Rose Lake, east of Thandlät and at similar elevation (ca. $1900 \mathrm{~m}$ ) (Greer, 1986). Although no constructed hunting blind is present at Thandlät, hunters might have used a prominent line of boulders that rims the upper edge of the snow patch (Fig. 5) as a natural blind.

The Thandlät site is located within a half-day's hike of Kusawa Lake, a traditionally important summer fishing lake and the site of annual trading between local Southern Tutchone and Tlingit from the Alaskan coast. Limited archaeological investigations at the Kusawa bluff site (JdVa-2), located on the west side of the lake outlet, indicate the site was contemporaneous with the hunting episode on Thandlät. The recovery of bison (Bison bison) and elk (Cervus elaphus) bone from the site, dated at 45005500 radiocarbon years B.P., suggests a more complex resource mosaic and subsistence pattern for First Nation people in the mid-to-late Holocene than is documented in the historical period (Greer, 1986).

Further research on alpine snow patches in southern Yukon should contribute significantly to a better understanding of subsistence and technological change over the past 4000 years. The potential for recovery of additional organic remains associated with alpine hunting provides a unique opportunity to shed light on ancient hunters and their caribou prey. We expect that the rapidly melting deposits will provide rare insights into caribou ecology and distribution through time, including factors such as changes in health, diet, and genetic make-up.

\section{ACKNOWLEDGEMENTS}

The support and assistance of Diane Strand and Sarah Gaunt of the Champagne and Aishihik First Nations Heritage Office in providing place name and traditional use information is gratefully acknowledged. Art Johns of the Carcross/Tagish First Nation assisted in the interpretation of the site and documentation of caribou distribution in the area. Helicopter support for work at Thandlät was provided by the Canadian Wildlife Service and the Government of Yukon Department of Renewable Resources. Sample dating and coring work was supported by the Government of Yukon Heritage Branch. Coring equipment was kindly loaned to the project by Dr. Roy M. Koerner of the Geological Survey of Canada. We would like to acknowledge Kristin Benedek for her initial observations and curiosity, which stimulated further research at the site.

\section{REFERENCES}

ACKERMAN, R.E. 1996. Lime Hills, Cave 1. In: West, F.H., ed. American beginnings: The prehistory and paleoecology of Beringia. Chicago: University of Chicago Press. 470-475.

BLITZ, J.H. 1988. Adoption of the bow in prehistoric North America. North American Archaeologist 9(2):123-145.

BOERTJE, R.D., and GARDNER, C.L. 1996. Factors limiting the Fortymile herd. Research Progress Report. Fairbanks: Alaska Department of Fish and Game. 79 p.

CRUIKSHANK, J. 1985. Contributions to the oral history of the Kusawa Lake region, Yukon Territory, from Mrs. Annie Ned. Report prepared for Archaeological Survey of Canada, National Museum of Man, National Museums of Canada. Available at the Yukon Heritage Branch, Box 2703, Whitehorse, Yukon Y1A 2C6, Canada. 26 p. 
DE LAGUNA, F. 1972. Under Mount Saint Elias: The history and culture of the Yakutat Tlingit. Smithsonian Contributions to Anthropology 7. Washington, D.C.: Smithsonian Institution. $1395 \mathrm{p}$.

EMMONS, G. 1991. The Tlingit Indians. Edited, with additions, by F. de Laguna. Vancouver/Toronto: Douglas and McIntyre. $488 \mathrm{p}$.

FARNELL, R., BARICHELLO, N., EGLI, K., and KUZYK, G. 1996. Population ecology of two woodland caribou herds in southern Yukon. Rangifer, Special Issue 9:63-72.

GREER, S. 1986. Kusawa Lake archaeology: Management, research and interpretation. Report prepared for the Archaeological Survey of Canada, National Museum of Man, National Museums of Canada and Parks Planning, Department of Renewable Resources, Government of Yukon. Available at the Yukon Heritage Branch, Box 2703, Whitehorse, Yukon Y1A 2C6, Canada. 87 p.

HOEFS, M., and McTAGGART-COWAN, I. 1979. Ecological investigations of a population of Dall sheep (Ovis dalli dalli Nelson). Syesis 12: Supplement 1.81 p.
HUTCHINGS, K.W., and BRÜCHERT, L.W. 1997. Spearthrower performance: Ethnographic and experimental research. Antiquity 71:890-897.

ION, P.G., and KERSHAW, G.P. 1989. The selection of snow patches as relief habitat by woodland caribou (Rangifer tarandus caribou), Macmillan Pass, Selwyn/Mackenzie Mountains, N.W.T., Canada. Arctic and Alpine Research 21(2):203-211.

McCLELLAN, C. 1975. My old people say: An ethnographic survey of southern Yukon Territory. Publications in Ethnology 6. Ottawa: National Museums of Canada. 637 p.

McGHEE, R. 1989. Ancient Canada. Ottawa: Canadian Museum of Civilization. 175 p.

O'DONOGHUE, M. 1996. Southern Lakes caribou recovery program. Progress Report 1992-1996. Available at: Council of Yukon First Nations. 11 Nisutlin Drive, Whitehorse, Yukon Y1A 3S4, Canada. 23 p.

RUSSELL, D., MARTELL, A., and NIXON, W. 1993. Range ecology of the Porcupine Caribou herd in Yukon. Rangifer, Special Issue $8.168 \mathrm{p}$. 